\title{
Wastewater Treatment and Possibility of Agriculture Reuse in El-Oued Region (North East Sahar Algeria)
}

\author{
A. Serraye and T. Idder \\ University Kasdi-Merbeh, Department of Biology, Ouargla, Algeria
}

\begin{abstract}
Like many cities in the Algerian Sahara, the city of El-Oued suffers from an acute problem of urban water surpluses that caused the rise of the surface ply and the deterioration of sanitary conditions in the oasis. The treatment of urban wastewater by aerated lagoons and discharge of treated water into a natural outlet located $45 \mathrm{~km}$ north of the agglomeration was the solution adopted by governments to deal with this alarming situation. The main objective of our work is to evaluate the effectiveness of the treatment technique in lagoons Saharan climate and examine the possibilities of valorization the treated water for reuse in irrigation. The average yields for the main pollution parameters were generally significant.

For BOD5, COD and TSS, the yields were respectively, $83.0 \%, 81.45 \%$ and $79.14 \%$ but they are not comply with Algerian norms instructions of treated wastewater irrigation.

For faecal coliforms, faecal streptococci and helminthes, we obtained respective yields of $96.18 \%, 65.75 \%$ and $100 \%$. These values are valid for mobilization in irrigation.

The results announce a fairly good adaptation of lagooning as an urban wastewater treatment technique for this region, and consequently to all the agglomerations of the Saharan environment.
\end{abstract}

Keywords: Excess water, aerated lagoons, treatment performance, Algerian Sahara, El-Oued city, irrigation.

\section{Introduction}

El-Oued city is a region that belongs to the North-East of the Algerian Sahara; In this last years, it has been confronted with a problem of upwelling phreatic water that has invaded the lower parts of the agglomeration. This phenomenon has had very negative environmental consequences, such as the spread of dangerous insects, which are the cause of waterborne diseases (cutaneous diseases, leishmaniasis, malaria, typhoid, etc.).

Authorities have adopted wastewater treatment technique by aerated lagoons since 2009 as the more appropriate solution for the Saharan ecosystem.

Our study carried out in the laboratory of O.N.A (National Office of Sanitation) and hygiene laboratory (DAAS), aims to determine the treatment performance of the wastewater treatment plant regarding to reduction of urban waters pollution even possibility of reuse for agricultural purposes without health risks.

\section{Methodology of the Study}

Our methodological approach consists of evaluating the effectiveness of urban water management system put in place to combat the problem of rising groundwater and its consequences on the agglomeration.

In order to measure the purification performance of El-Oued WWTP 1, monitoring of physicochemical, bacteriological and parasitological characteristics of raw wastewater and treated water has been done. To these objectives just mentioned, a preliminary evaluation of lagooning effectiveness in the Saharan environment is another aim to add to it. This will be done by comparing the obtained results in the wastewater treatment plant in El-Oued city with Algerian and international standards. 


\section{Sampling Methodology and Measurement}

Depending on the type and purpose of analyzes, Samples are taken at several points at the entrance and exit of the station.

The sampling frequency was three times a week from January to December 2016 for the following parameters: COD (Chemical Oxygen Demand), BOD5 (Biochemical Oxygen Demand), MES (Suspended Substances).

We have done a search and enumeration of the following germs: faecal coliforms, faecal streptococci. For parasitological analyzes, 12 samples of 04 liters were taken between $17 \mathrm{~h}$ and $19 \mathrm{pm}$. Each sample is fixed by addition of formalin (10\%) (2 ml / 1) and transported to Parasitology Laboratory Teaching Hospital to count eggs helminth.

\section{Results And Discussion}

Regarding organic parameters, Fig. 01 shows that the weekly average concentrations of COD of raw water amount to above $192 \mathrm{mg} / 1$ (week 24) from the month of June so that they reach $920 \mathrm{mg} / 1$ in the month of July (week 29)

Output values range from $32 \mathrm{mg} / 1$ in October (week 41) to $173 \mathrm{mg} / \mathrm{l}$ in May (week 19) with an average of $95.27 \mathrm{mg} / 1$.

These values indicate a good reduction of aerated basins with respect to carbon pollution. On the other hand, the recorded values are above Algerian standard $(90 \mathrm{mg} / 1)$ [1], so they are not compliant for irrigation. COD evolves in the opposite direction with dissolved oxygen, which indicates a probable use of oxygen for degradation of carbonaceous material [2].

The average yield of these 12 months of experimentation of the order of $81.45 \%$ perfectly informs on the effectiveness of WWTP basins of El-Oued in the treatment of this type of pollution.

BOD5 is an expression to indicate the amount of oxygen, which is used for the destruction of decomposable organic matter by biochemical, processes [3].

The weekly concentrations of BOD5 throughout the year 2016 measured at entry range from $106 \mathrm{mg} / 1 \mathrm{in}$ November (week 46) to $351.60 \mathrm{mg} / 1$ in August (week 31) with an average of of $222.59 \mathrm{mg} / 1$.

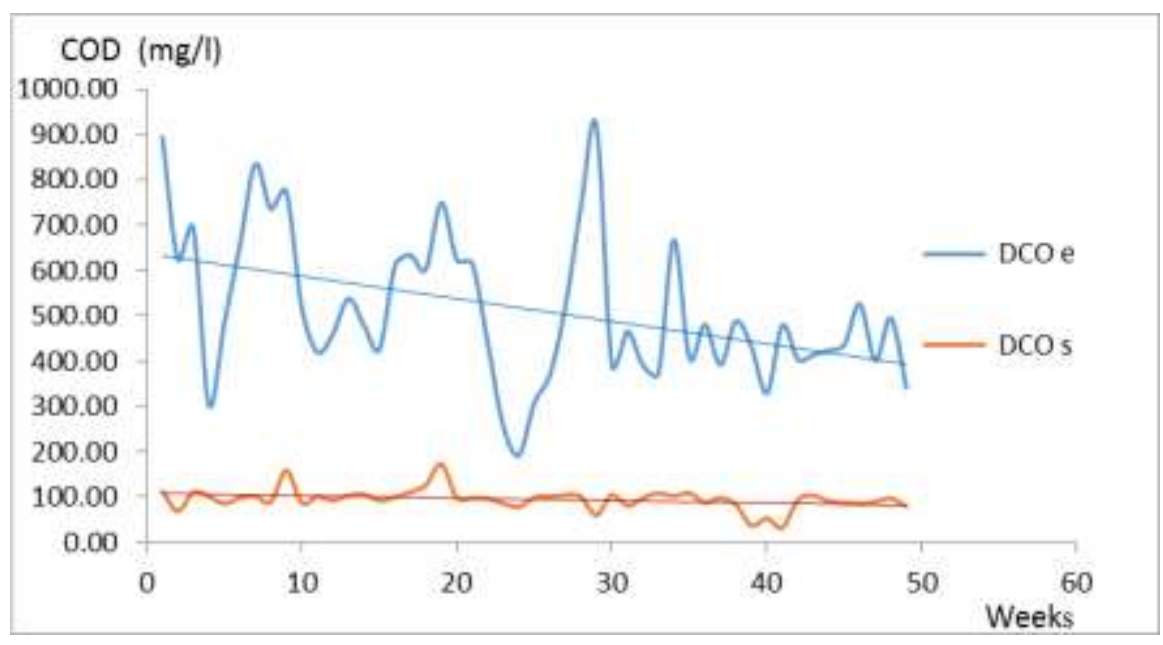

Fig. 1: Weekly evolution of the COD during the year 2016.

Mean values at the outlet range from $10 \mathrm{mg} / 1$ in June (week 25) to $130 \mathrm{mg} / 1$ in May (week 21), an average of $71.01 \mathrm{mg} / 1$ (fig 01). The values recorded are above Algerian norm (30 mg / 1); they are not suitable for agricultural irrigation. 
MES results analysis (Fig. 02) shows that the studied wastewater is characterized by an average concentration of $268.39 \mathrm{mg} / 1$ for raw wastewater and $55.96 \mathrm{mg} / 1$ for treated wastewater. SS concentration of raw wastewater fluctuates wildly between a low of $122.22 \mathrm{mg} / \mathrm{l}$ in October (week 40) and a high of $380 \mathrm{mg} / 1$ in August (week 30). That of the exit of WWTP, it oscillates around a minimum of $33.33 \mathrm{mg} / 1$ in the month of August (week 30) and a maximum of $73.86 \mathrm{mg} / 1$ in the month of February (week 8) with an average of 55.96 $\mathrm{mg} / 1$. However, It is however known.

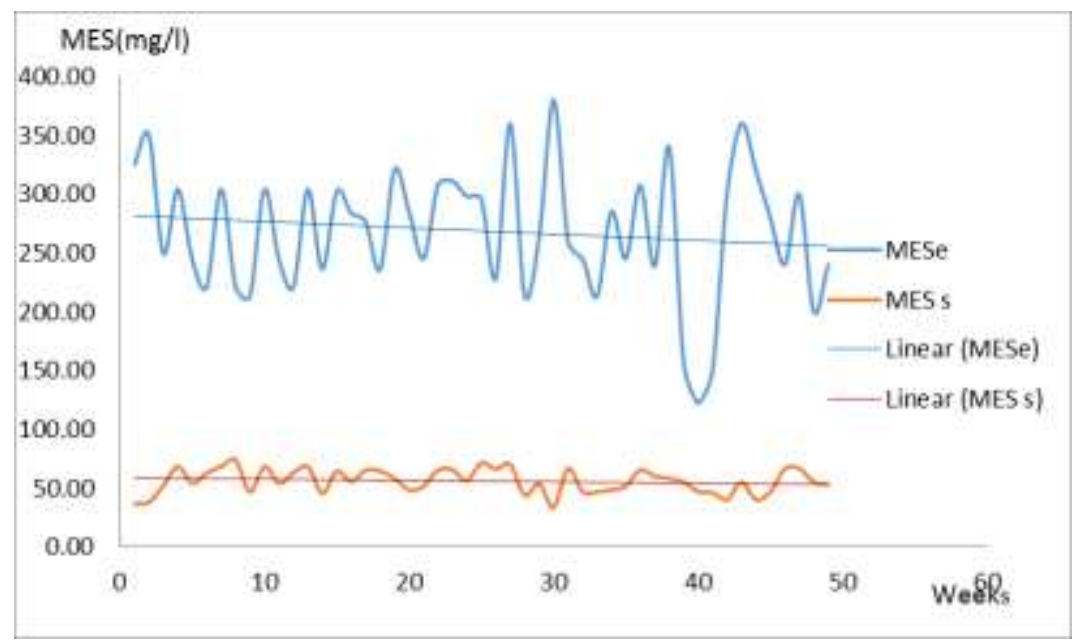

Fig. 2: Weekly evolution of the MES during the year 2016.

That it is difficult to obtain lower values by the lagooning process, especially if the outlet basins are the site of intense photosynthesis [4]. The purging SS performance of aerated basins is very significant, around 79.14\% throughout the year. In addition, the comparison of suspended solids content in WWTP of Kouinine with Algerian standard (30 mg / ) shows that these levels are not suitable for agricultural irrigation.

Bacteriological results indicating a significant decrease in faecal coliforms of $96.18 \%$ and faecal streptococci of $65.75 \%$ attest to a very satisfactory role played by this treatment plant in the decontamination of raw wastewater.

The parasitological study (Fig. 03) revealed the total absence of helminth eggs at the exit of WWTP, the treated water no longer contains eggs.

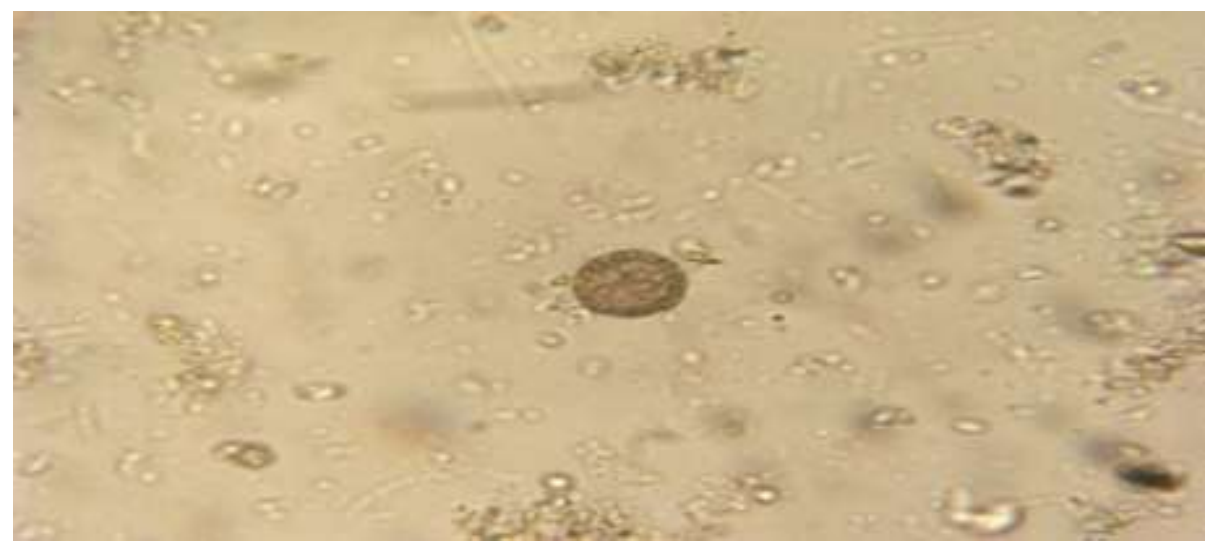

Fig. 3: Taenia humenolepis nana in raw waste water under a microscope $(\boldsymbol{G} \times 40)$

\section{Conclusion}

In the absence of a natural outlet surpluses water, the groundwater has progressively increased to the point of flooding hundreds Ghouts and consequently the death of thousands date palms; this situation has also 
contributed to deterioration of the living conditions of the population, especially in the large agglomeration of El-Oued.

The aerated lagoons treatment plant has considerably reduced a various types of pollution thanks to its overall interesting purification performances

It helped to significantly reduce BOD5, COD and MES respectively by $83.09 \%, 81.45 \%$ and $79.14 \%$. The respective yields obtained for faecal coliforms, faecal streptococci were $96.18 \%, 65.75 \%$.

The purification performance of STEP1 in El-Oued city is therefore satisfactory for some elements and not for others.

We have shown that the treated wastewater, taking into account their microbiological qualities, could be reused for a restrictive irrigation of fodder shrubs, various cereal, industrial crops, fruit and forest trees, floral and ornamental plants. despite their relatively high electrical conductivity, still announce a fairly good adaptation of lagooning as an urban wastewater treatment technique for this region, and consequently to all the agglomerations of the Saharan environment.

Finally, we can exploit this treated wastewater by lagoon system in irrigation of date palm thanks to its soil salinization resistance who presents an ancestral heritage in this Saharan city that we must not let disappear.

\section{References}

[1] A.B.H.S. (Hydrographic Basin Agency of the Sahara), 2011. missions reports and companions carried out by the ABHS, Wilaya of El-Oued.

[2] BAHLAOUI A., 2000. Dynamics of wastewater treatment ecosystems by lagooning: Spatio-temporal analysis of the effects of environmental factors, PhD Es-Science, Mohammadia School of Engineering, Mohammed V University, Rabat, Morocco, 218p.

[3] INTERMINISTERIAL ORDER, 2012. Specifications for treated wastewater used for irrigation purposes. Official Gazette No. 41 of the People's Democratic Republic of Algeria. Corresponding to July 15, 2012. 27p.

[4] KONE D., 2002. Treatment of wastewater by microphyte and macrophyte lagooning in West and Central Africa: state of play, purification performance and di- mensioning criteria. Thesis for obtaining Doctor Es Science Techniques in the field of sciences and engineering of the environment. Faculty natural, architectural and construction environment. Federal Polytechnic School of Lausanne.170p. 